\title{
CYTOKINE AND NITRIC OXIDE PRODUCTION BY MOUSE MACROPHAGES INFECTED WITH BRAZILIAN FLAVIVIRUSES
}

Veridiana Ester Dias BARROS(1), Beatriz Rossetti FERREIRA(2), Márcia LIVONESI(1) \& Luiz Tadeu Moraes FIGUEIREDO(1)

\begin{abstract}
SUMMARY
The Flaviviridae family, Flavivirus genus includes viruses that are transmitted to vertebrates by infected mosquitoes or ticks. The genus Flavivirus includes a variety of viruses that cause diseases such as acute febrile illness, encephalitis, and hemorrhagic fever. Flaviviruses primarily infect blood monocytes and tissue macrophages, which have been shown to be permissive, supporting viral replication and serving as virus reservoirs. On the other hand, these cells may have an important antiviral activity related to modulation by cytokine production and by the capacity of these cells to synthesize reactive free radicals such as nitric oxide (NO) which can have a microbicidal effect. The present study was performed in order to determine the production of cytokines interleukin1 beta (IL-1 $\beta$ ), tumor necrosis factor -alpha (TNF- $\alpha$ ), transforming growth factor- beta (TGF- $\beta$ ) and interferon -alpha (IFN- $\alpha$ ) and NO by macrophages infected with one of four Brazilian flaviviruses, Bussuquara virus (BUSV), Yellow Fever virus (YFV), Rocio virus (ROCV) and Encephalitis Saint Louis virus (SLEV), and to verify the possible antiviral effect of NO during macrophage infection with ROCV. Moreover, we asked if the different viruses were able to regulate bacterial lipopolysaccharide (LPS) induced cytokine production. Our results showed that YFV and SLEV reduced the production of IL-1 $\beta$ and TGF- $\beta$ by LPS-stimulated macrophages, while ROCV only diminished LPS-stimulated TGF- $\beta$ synthesis. On the other hand, BUSV more likely favored an enhancement of the LPS-induced production of IL- $1 \beta$ by macrophages. Additionally, while most of the viruses stimulated the production of IFN- $\alpha$, none of them altered the production of TNF- $\alpha$ by murine macrophages. Interestingly, all viruses induced synthesis of NO that was not correlated with antiviral activity for ROCV.
\end{abstract}

KEYWORDS: Flavivirus; Macrophages; Cytokines; Nitric Oxide

\section{INTRODUCTION}

The Flaviviridae family, genus flavivirus currently includes 68 members ${ }^{38}$ mostly transmitted to vertebrates by infected mosquitoes or ticks. The life cycle of these arthropod-borne viruses involves a complex relationship among arthropod vectors, vertebrate reservoirs, humans and environment ${ }^{4}$. Flaviviruses are small enveloped viruses with an infectious single-stranded RNA genome of approximately 11 kilobases encoding genes for three structural (capsid [C], pre-membrane/membrane [prM/M], and envelope $[\mathrm{E}]$ ) and seven non-structural proteins ${ }^{3}$. Flaviviruses attach to the surface of host cells through an interaction of the E protein with one or more receptors and this interaction can be blocked by E-reactive antibodies $^{22}$. It has been suggested that the E protein may also mediate the antibody-dependent enhancement (ADE) of the infectious phenomenon, which has been implicated in the pathogenesis of dengue haemorrhagic fever/dengue shock syndrome (DHF/DSS) ${ }^{10}$.

The genus flavivirus includes a variety of viruses that produce human acute febrile illness, encephalitis, and haemorrhagic fever. Type
1, 2 and 3 dengue viruses circulate in Brazil producing large outbreaks of acute febrile illness and an increasing number of DHF/DSS cases. Several other flaviviruses have been isolated in Brazil, such as Ilhéus, Bussuquara (BUSV) and Saint Louis encephalitis virus (SLEV) that have been reported to cause acute febrile illness, Rocio virus (ROCV) that caused an encephalitis outbreak, sylvatic yellow fever virus (YFV) that produces dozens of severe hepatitis and hemorrhagic fever cases yearly, and other viruses such as Cacipacoré and Iguape that have not been reported to cause human disease ${ }^{16}$.

Macrophages are known to be important cells that participate in the pathogenesis of viral infections ${ }^{29}$. For flavivirus, macrophages seem to be permissive, supporting viral replication and serving as a virus reservoir ${ }^{25}$. On the other hand, these cells may have an important antiviral activity related to modulation of the inflammatory response via cytokine production ${ }^{17}$. Macrophages are also able to synthesize reactive free radicals, such as nitric oxide (NO) which can have an antiviral effect ${ }^{9,24}$. However, this antiviral activity of NO has been observed for only certain viruses, whereas others remain unaffected ${ }^{26}$.

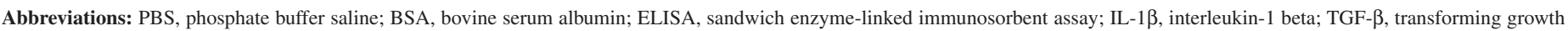

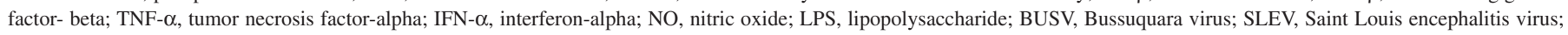
ROCV, Rocio virus; YFV, Yellow fever virus.

(1) Virology Research Center, School of Medicine, University of São Paulo in Ribeirão Preto, SP, Brazil.

(2) Department of Biochemistry and Immunology, School of Medicine, University of São Paulo in Ribeirão Preto, SP, Brazil.

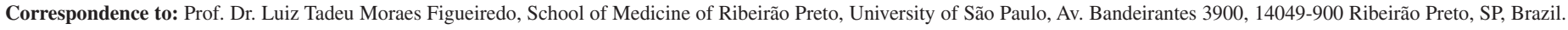
Phone: 55.16.6023271, Fax: 55.16.6336695. E-mail: ltmfigue@fmrp.usp.br 


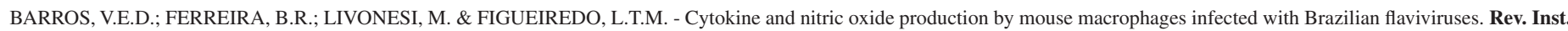
Med. trop. S. Paulo, 51(3): 141-147, 2009.

The present study was performed in order to determine the production of cytokines (IL- $1 \beta$, TNF- $\alpha$, TGF- $\beta$ and IFN- $\alpha$ ) and NO by macrophages infected with one of four Brazilian flaviviruses (BUSV, YFV, ROCV and SLEV), and to verify the possible antiviral effect of NO during macrophage infection with ROCV. Moreover, we asked if the different viruses were able to regulate bacterial lipopolysaccharide (LPS) induced cytokine production. Our results showed that YFV and SLEV reduced the production of IL- $1 \beta$ and TGF- $\beta$ by LPS-stimulated macrophages, while ROCV only diminished LPS-stimulated TGF- $\beta$ synthesis. On the other hand, BUSV more likely favored an enhancement of the LPS-induced production of IL- $1 \beta$ by macrophages additionally, while most of the viruses stimulated the production of IFN- $\alpha$, none of them altered the production of TNF- $\alpha$ by murine macrophages. Interestingly, all viruses induced synthesis of NO that was not correlated with antiviral activity for ROCV.

\section{MATERIALS AND METHODS}

Preparation of virus stocks: BUSV BeAn 4073 strain and YFV BeH111 strain were kindly supplied by Dr. Pedro Vasconcelos from Evandro Chagas Institute, Brazilian Ministry of Health, Belém, PA, Brazil. ROCV SPH 34675 and SLEV SPAn 11916 strains were kindly supplied by Dr. Terezinha Lisieux from Adolpho Lutz Institute, São Paulo State Ministry of Health, São Paulo, SP, Brazil. For virus seed preparation, each virus was propagated in suckling mouse brain. After developing encephalitis the animals were sacrificed and their brain extracts were stored at $-70^{\circ} \mathrm{C}$. Each virus had a titer of $\sim 1 \mathrm{X} 10^{10} \mathrm{LD} 50 /$ $\mathrm{mL}$ as determined by the Reed-Muench method ${ }^{33}$.

Peritoneal macrophages: C57BL/6 mice $(n=40)$ were injected intraperitoneally with $1 \mathrm{~mL}$ of $3 \%$ thioglycolate (Difco Laboratories, Detroit, MI) in phosphate buffer saline (PBS) and the cells were harvested four days later by rinsing the peritoneum with cold RPMI-1640 solution containing $40 \%$ sodium citrate. The macrophages, pooled from different animals were centrifuged for $10 \mathrm{~min}$ at $150 \mathrm{x} \mathrm{g}$, washed three times and diluted in RPMI-1640 supplemented with heat-inactivated 5\% fetal calf serum, 5 x $10^{-5} \mathrm{M}$ 2-mercaptoethanol, $2 \mathrm{mM}$ L-glutamine, and antibiotics (Gibco-BRL Life Technologies, Grand Island, NY). Two x $10^{6}$ cells per well were seeded onto 24 well flat-bottom culture plates in duplicate. Macrophages were allowed to adhere to the plate for two h at $37{ }^{\circ} \mathrm{C}$ in a humidified 5\% CO incubator. Finally, the non-adherent cells were washed off with PBS ${ }^{2}$ and the adherent cells were infected.

Infection of macrophage cultures: The infections were produced by adding viruses at MOI of 500 with BUSV, YFV, ROCV or SLEV to the macrophage cultures for two $\mathrm{h}$ at $37{ }^{\circ} \mathrm{C}$, in a humidified $5 \% \mathrm{CO}_{2}$ incubator. Next, the cells were extensively washed and incubated with or without LPS ( $5 \mu \mathrm{g} / \mathrm{mL}$, Difco). Non-infected control macrophages were also incubated in the presence or absence of LPS. The supernatants were harvested 24 and $48 \mathrm{~h}$ after infection, aliquoted and stored at $-20^{\circ} \mathrm{C}$ until use. The infectious viral dose was established based on preliminary experiments using 1, 50, 500 and 5000 MOI.

IL-1 $\beta$, TNF- $\alpha$, TGF- $\beta$ and IFN- $\alpha$ assays: Levels of IL- $1 \beta$ and TNF- $\alpha$ in the supernatants of the macrophage cultures were determined using a two-site sandwich enzyme-linked immunosorbent assay (ELISA), as previously described ${ }^{8,15}$. For IL- $\beta$, the monoclonal antibody MAb 303011.11 was used with an anti-mouse IL-1 $\beta$ polyclonal antibody, while for TNF- $\alpha$ polyclonal anti-mouse TNF- $\alpha$ antibodies were used. These antibodies were purchased from (R\&D Systems, Minneapolis, MN, USA) and used according to instructions of the fabricant. All tests were set up in duplicate and the optical density at $492 \mathrm{~nm}$ was determined with a microplate reader spectrophotometer (EMAX Molecular Devices Corporation, Ramsey, MN, USA). The cytokine concentration of each sample was determined with reference to a standard curve constructed with serially diluted recombinant proteins (R\&D Systems, Minneapolis, MN, USA). TGF- $\beta$ was determined with an ELISA kit (Promega, Madison, WI, USA). For the detection of active TGF- $\beta$, all samples were previously submitted to acidification according to manufacturer instructions. The minimum detectable concentrations of IL- $1 \beta$, TNF- $\alpha$ and TGF- $\beta$ in these assays were $62.5,125.0$ and $31.2 \mathrm{pg} / \mathrm{mL}$, respectively. An ELISA kit (PBL Biomedical Laboratories, New Brunswick, NJ, USA) was used for the detection of IFN- $\alpha$ and tests were done according to manufacturer instructions. Experiments were repeated at least three times.

Determination of nitric oxide (NO) production: $\mathrm{NO}$ was quantified in 24 and $48 \mathrm{~h}$ after infection (a.i.) in macrophage culture supernatants in the presence or absence of LPS $(5 \mu \mathrm{g} / \mathrm{mL})$. NO was determined by quantifying nitrite $\left(\mathrm{NO}_{2}^{-}\right)$using the Griess reagent as previously described $^{13}$. Briefly, equal volumes of a test sample and Griess reagent (1\% sulfanilamide, $0.1 \%$ naphthylethylene diamine dihydrochloride, $5 \%$ phosphoric acid) were incubated at $37{ }^{\circ} \mathrm{C}$ for $10 \mathrm{~min}$. Absorbance was measured at $540 \mathrm{~nm}$ in a microplate reader spectrophotometer (EMAX Molecular Devices Corporation, Ramsey, MN, USA). The nitrite concentration of each sample was determined with reference to a standard curve constructed with serially diluted sodium nitrite. The minimum detectable concentration in this assay was $0.195 \mu \mathrm{M}$ nitrite. Experiments were repeated at least three times

Indirect evaluation of macrophage virucidal activity: Macrophage cultures were performed in 24-well flat-bottom culture plates, in duplicate, at $2 \times 10^{6}$ cells per well. The cells were infected with ROCV at MOI of 500 for two h, the unabsorbed viruses were removed, and the cultures were washed and replenished with fresh culture medium with or without $\mathrm{N}^{\mathrm{G}}$-monomethyl-L-arginine ( $2 \mathrm{mM}$ ) (L-NMMA, Sigma). After four days, the supernatants were collected and injected intracerebrally (IC) (undiluted, 1:10, 1:100, 1:1000 and 1: 10000 in RPMI-1640; $20 \mu \mathrm{L} /$ animal) in six suckling mouse litters viral LD50 titers were determined by the Reed-Muench method and the mortality rates were evaluated daily for 10 days $^{33}$. Control mice were inoculated IC with supernatants from non-infected macrophage cultures treated or not with L-NMMA.

Statistical analysis: The results were expressed as mean \pm SD. Statistical analysis was performed using analysis of variance followed by the parametric Tukey-Kramer test (INSTAT software, GraphPad, San Diego, CA, USA). $p$ values $<0.05$ were considered significant.

\section{RESULTS}

Cytokine production induced by flavivirus infection: The contribution of macrophages to the host production of cytokines was investigated in vitro by analysis of supernatants of mouse macrophage cultures infected with BUSV, ROCV, YFV or SLEV at MOI of 500. None of the virus infections stimulated or reduced macrophage production of IL- $1 \beta$, TNF- $\alpha$ and TGF- $\beta$ during the a.i., time periods 
analyzed when compared to non-infected cell cultures (Fig. 1, 2 and 3 ). In addition, as expected, LPS stimulated the production of IL-1 $\beta$,

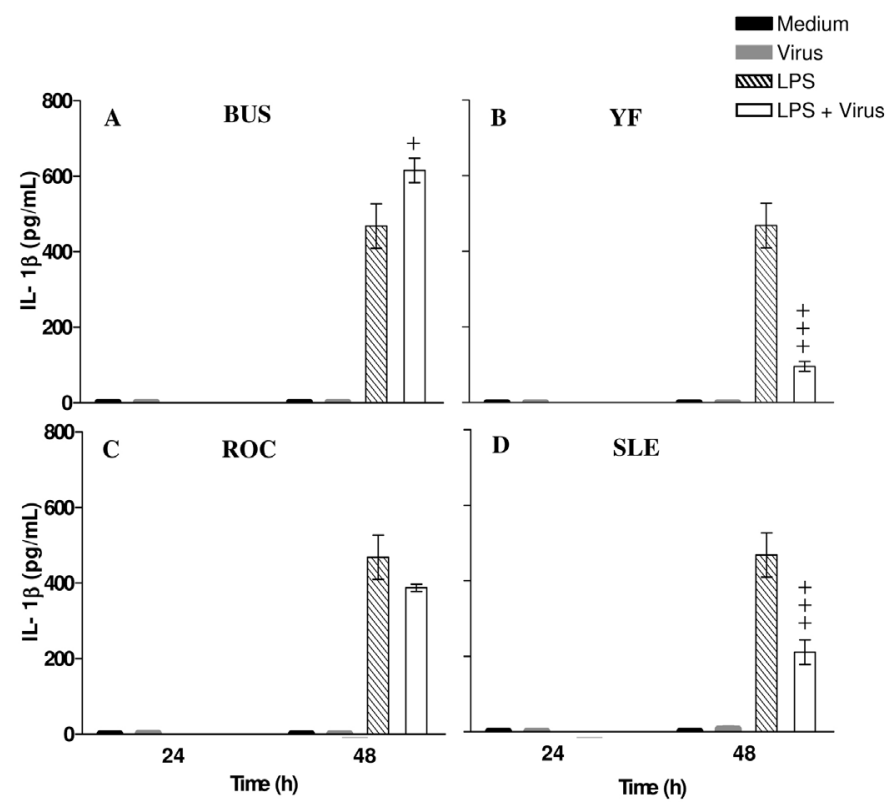

Fig. 1 - Production of IL-1 $\beta$ by BUSV, YFV, ROCV and SLEV infected peritoneal macrophages. Mouse macrophages were cultured $\left(2 \times 10^{6}\right.$ cells per well) in the presence or absence of the specific virus (500 MOI) with or without LPS $(5 \mu \mathrm{g} / \mathrm{mL})$. Supernatants were collected after 24 and $48 \mathrm{~h}$ and assayed for IL- $1 \beta$ by specific ELISA. $+p<0.05 ;+++p<$ 0.001 compared with macrophages stimulated with LPS. Results are expressed as the mean of duplicate of two different experiments $\pm \mathrm{SD}$, and represent data of four independent experiments.

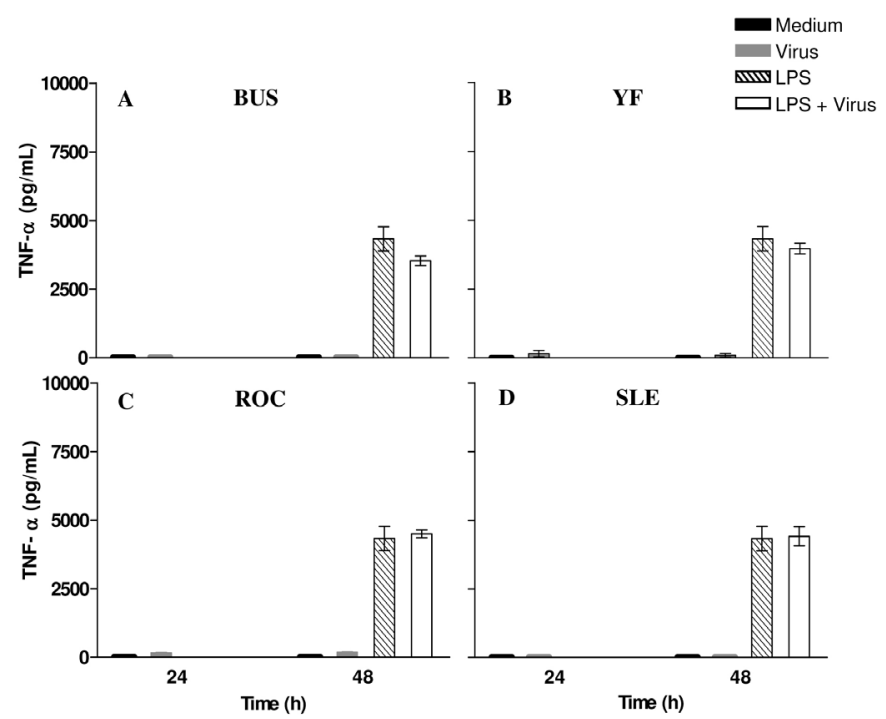

Fig. 2 - Production of TNF- $\alpha$ by BUSV, YFV, ROCV and SLEV infected peritoneal macrophages. Mouse macrophages were cultured $\left(2 \times 10^{6}\right.$ cells per well) in the presence or absence of the specific virus (500 MOI) with or without LPS $(5 \mu \mathrm{g} / \mathrm{mL})$. Supernatants were collected after 24 and $48 \mathrm{~h}$ and assayed for TNF- $\alpha$ by specific ELISA. Results are expressed as the mean of duplicate of two different experiments $\pm \mathrm{SD}$, and represent data of four independent experiments.
TNF- $\alpha$ and TGF- $\beta$ by the cell cultures (Figs. 1, 2 and 3). However, when macrophages were infected with YFV or SLEV and subsequently stimulated with LPS, the IL- $1 \beta$ production was inhibited $(p<0.001$; Fig. 1B and D, respectively). In contrast, this inhibition was not observed in macrophage cultures infected with ROCV at MOI of 500 and stimulated with LPS (Fig.1C). When the macrophage infected was performed with a higher concentration of ROCV at MOI of 5000, a $65 \%$ statistically significant inhibition of IL- $1 \beta$ production was observed compared to non-infected cell cultures stimulated with LPS ( $p<0.001$, data not shown). Differently from the other flaviviruses studied, BUSV infection produced a slight additional effect on IL-1 $\beta$ synthesis $(p<0.01)$ stimulated by LPS compared to similarly stimulated non-infected macrophages (Fig. 1A). LPS-induced TNF- $\alpha$ production by macrophages was not changed by BUSV, ROCV, YFV or SLEV infection (Fig. 2).

The production of TGF- $\beta$ by peritoneal murine macrophages infected with flavivirus and stimulated with LPS is depicted in Fig. 3. Although BUSV did not impair LPS-induced TGF- $\beta$ production; YFV, ROCV and SLEV did so ( $p<0.001, p<0.01$ and $p<0.001$, respectively), as shown in Fig.3.

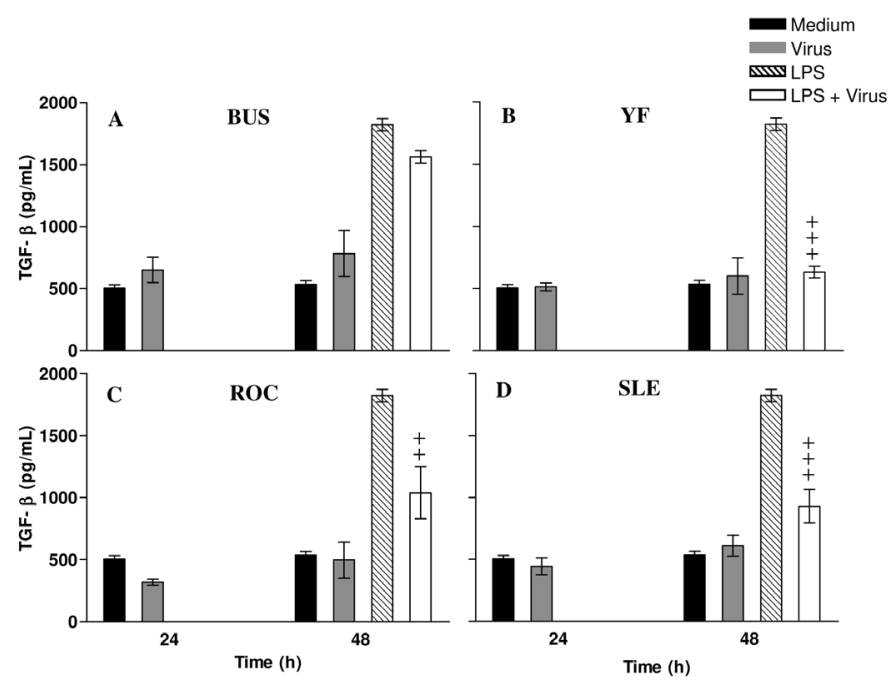

Fig. 3 - Production of TGF- $\beta$ by BUSV, YFV, ROCV and SLEV infected peritoneal macrophages. Mouse macrophages were cultured $\left(2 \times 10^{6}\right.$ cells per well) in the presence or absence of the specific virus (500 MOI) with or without LPS $(5 \mu \mathrm{g} / \mathrm{mL})$. Supernatants were collected after 24 and $48 \mathrm{~h}$ and assayed for TGF- $\beta$ by specific ELISA. $++p<0.01$ and $+++p$ $<0.001$ compared with macrophages stimulated with LPS. Results are expressed as the mean of duplicate of two different experiments $\pm \mathrm{SD}$, and represent data of four independent experiments.

Differently from the other cytokines, IFN- $\alpha$ production by the macrophages was augmented after $24 \mathrm{~h}$ of infection by BUSV, YFV and SLEV, compared to the non-infected cells $(p<0.05, p<0.05$ and $p<0.001$, respectively), as shown in Fig.4. Additionally, ROCV and SLEV stimulated the production of IFN- $\alpha 48 \mathrm{~h}$ p.i., $(p<0.001$ and $p<0.001$, respectively) while BUSV and YFV did not, as shown in Fig. 4. Finally, no change in IFN- $\alpha$ production was observed in the cell culture supernatants for any of the viruses analyzed when the macrophages were infected and subsequently stimulated with LPS (Fig. 4). 


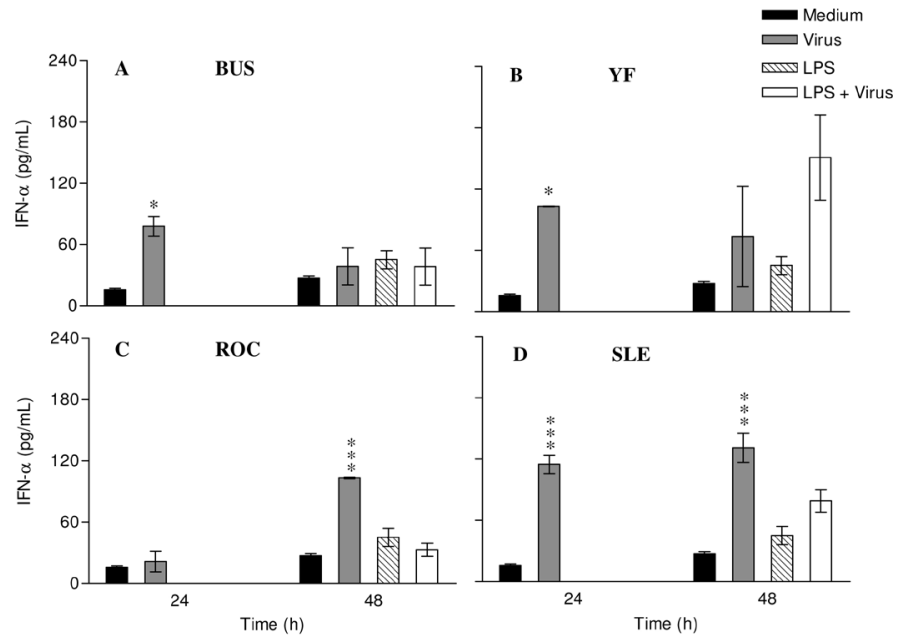

Fig. 4 - Production of IFN- $\alpha$ by BUSV, YFV, ROCV and SLEV infected peritoneal macrophages. Mouse macrophages were cultured $\left(2 \times 10^{6}\right.$ cells per well $)$ in the presence or absence of the specific virus (500 MOI) with or without LPS $(5 \mu \mathrm{g} / \mathrm{mL})$. Supernatants were collected after 24 and $48 \mathrm{~h}$ and assayed for IFN- $\alpha$ by specific ELISA. ${ }^{*} p<0.01 ; * * * p<$ 0.001 compared with non-infected cells. Results are expressed as the mean of duplicate of two different experiments $\pm \mathrm{SD}$, and represent data of two independent experiments.

NO production induced by flavivirus infection: Stimulated by a previous study showing that, after tick-borne encephalitis flavivirus infection, mouse macrophages produced NO spontaneously ${ }^{26}$ and iNOS expression in activated monocytes was observed in patients with dengue fever $^{30}$, we analyzed the production NO by macrophages after in vitro infection with BUSV, YFV, ROCV and SLEV. Interestingly, the four flaviviruses stimulated NO production when these cells were compared with non-infected macrophages. The stimulated NO production by flavivirus-infected macrophages increased significantly 24 h p.i., $(p<$ 0.001) and the phenomenon persisted at $48 \mathrm{~h}$ p.i., (Fig. 5).

As expected, LPS-stimulated macrophages produced higher amounts of NO than non-stimulated ones. When murine macrophages were infected with ROCV and SLEV and subsequently stimulated with LPS, additional NO production ( $p<0.01$ and $p<0.001$, respectively) was observed. On the other hand, YFV reduced the effect of LPS $(p<0.001)$ in the infected macrophages and BUSV left unchanged the LPS-induced synthesis of NO.

NO production and flavivirus replication: Since all tested flaviviruses induced macrophage NO production and since NO shows anti-viral activity against both DNA and RNA viruses through mechanisms such as inhibition of viral genome synthesis, nitrosylation of viral proteins, and promotion of viral clearance by host cells ${ }^{1}$, mouse macrophages were infected with ROCV at MOI of 500. The cells were extensively washed and 2mM L-NMMA, a competitive inhibitor of nitric oxide synthase (NOS), was added to half of these colonies. After four days, the cell supernatants were collected, assayed for NO, and four10-fold dilutions of these supernatants were injected IC in suckling mice to establish the mortality rate and viral LD50 titers. This assay was performed to indirectly evaluate macrophage virucidal activity. The data presented in Table 1 show that even macrophages infected in the presence of L-NMMA, which produced much less NO, did not alter the

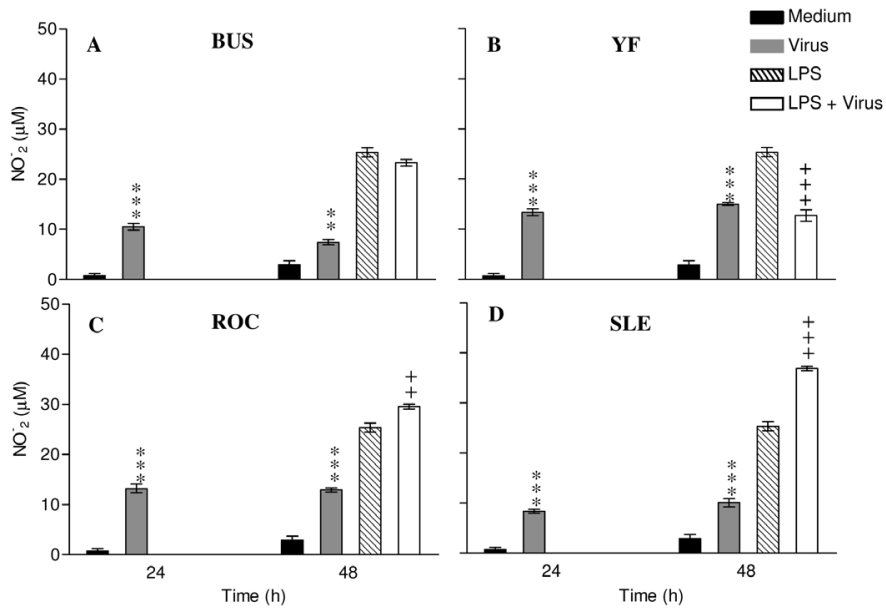

Fig. 5 - Production of NO by BUSV, YFV, ROCV and SLEV infected peritoneal macrophages. Mouse macrophages were cultured $\left(2 \times 10^{6}\right.$ cells per well) in the presence or absence of the specific virus (500 MOI) with or without LPS $(5 \mu \mathrm{g} / \mathrm{mL})$. Supernatants were collected after 24 and $48 \mathrm{~h}$ and nitrite $\left(\mathrm{NO}_{2}^{-}\right)$was measured in the supernatants using the Griess reagent. $++p$ $<0.01 ;+++p<0.001$ compared with macrophages stimulated with LPS; ** $p<0.01$; *** $p$ $<0.001$ compared with non-infected cells. Results are expressed as the mean of duplicate of two different experiments $\pm \mathrm{SD}$, and represent data of four independent experiments.

Table 1

Mortality rate induced by intracerebral inoculation of supernatants obtained from murine macrophages infected with Rocio and co-cultured with L-NMMA

\begin{tabular}{lccc}
\hline & Control & Virus infected & $\begin{array}{c}\text { Virus infected } \\
\text { + L-NMMA }\end{array}$ \\
\hline $\begin{array}{l}\text { Mortality } \\
(\text { dead/total })\end{array}$ & $0 / 6$ & $4 / 6$ & $4 / 6$ \\
$\mathrm{NO}_{2}^{-}(\mu \mathrm{M} / \mathrm{mL})$ & $2.58 \pm 0.21$ & $7.52 \pm 0.28$ & $2.92 \pm 0.15$ \\
Viral titer & & $10^{2.8}$ & $10^{2.4}$ \\
$(\mathrm{LD} 50 / \mathrm{mL})$ & & & \\
\hline
\end{tabular}

viral infective rate since IC inoculation of their supernatants induced a mortality rate similar to that induced by the supernatants from only virus-infected macrophages. Additionally, the viral titers determined in the presence of L-NMMA showed $\sim 1$ X $10^{2.4} \mathrm{LD} 50 / \mathrm{mL}$, and in the absence of L-NMMA $\sim 1$ X $10^{2.8} \mathrm{LD} 50 / \mathrm{mL}$. Taken together, the data obtained suggest that, at least for ROCV, NO is not relevant in restraining virus infectivity.

\section{DISCUSSION}

The present study was undertaken to investigate the capacity of four Brazilian flaviviruses, BUSV, YFV, ROCV and SLEV, to infect and to modulate cytokine and $\mathrm{NO}$ production by murine peritoneal macrophages. Our data show that all tested viruses efficiently infected the macrophages in culture. However, large doses of virus were required for this infection and even so, not all cells were infected, suggesting a certain degree of natural resistance. Virus-infected macrophages were visualized by scanning and transmission electron microscopy, showing several 50-70 nm particles, probably related to newly formed virions, 


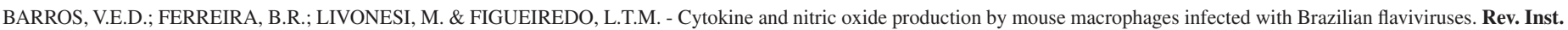
Med. trop. S. Paulo, 51(3): 141-147, 2009.

and cytopathological changes including hypertrophy, enlargement of membranous structures, increased amount of lysosomes and intense formation of phagosomes. Interestingly, these features were similar for all viruses tested $^{2}$. These data are on line with work showing that YFV and dengue (types 1,2 and 4) virus are also able to infect several types of cell line cultures and monocytes ${ }^{14,15}$. The experiments shown here were well standardized and we believe that the preparation of BUSV, YFV, ROCV and SLEV infected mouse brain homogenates, including centrifugation for removing cell debris, filtration thru a $.22 \mu \mathrm{m}$ pore filter, and dilution at $1 / 400$, removed the nervous tissue material that, eventually, could induce, by itself, cytokine production by macrophages.

Considering that peritoneal mouse macrophages were permissive for the Brazilian flaviviruses, and that they play an important role in the host immune response to viruses, we asked if viral infection could alter the cytokine production by macrophages, stimulated or not with LPS. None of the viruses tested altered per se the production of the cytokines IL- $1 \beta$, TNF- $\alpha$ and TGF- $\beta$ in the macrophage cultures. Nevertheless, BUSV, YFV and SLEV up-regulated the production of IFN- $\alpha$ within 24 $\mathrm{h}$ and the ROCV did so only at $48 \mathrm{~h}$ p.i. Other viruses have been shown to induce the production of diverse cytokines and chemokines after in vitro infection of different type of cells which correlate with disease severity ${ }^{5,7,18,27}$. IFN- $\alpha$ and $-\beta$ are known as type I IFNs and mediate the early innate immune response to several viral infections. They exhibit multiple biologic properties including antiviral and immunomodulatory effects $^{32,35}$. The contribution of IFN- $\alpha$ and $-\beta$ to the modulation of Flaviviridae infection has been shown in vitro and in vivo ${ }^{19,21,31,36}$. IFN- $\alpha$ and $-\beta$ inhibit dengue virus infection by significantly impairing either the production or the stability of negative-strand viral RNA, intracellular viral antigen, and infectious virus secreted into the cell supernatants ${ }^{11}$. Thus, the virus-induced up-regulation of IFN- $\alpha$ observed in the present study may possibly explain why we only noticed macrophage infection when these cells were submitted to large doses of virus.

Next we stimulated the virus-infected cells with LPS, a stimulus for cytokine synthesis. Using this protocol, three of the flaviviruses, YFV and SLEV viruses at MOI of 500 and ROCV virus at MOI of 5000 (data not shown) significantly reduced the production of IL-1 $\beta$ and TGF- $\beta$. IL- $1 \beta$ acts on multiple target cells to stimulate the immune and inflammatory responses to viral infection. Macrophages participate in several functions that influence the immune response ${ }^{28}$. Viral infection may influence accessory cell function by impairment of antigen processing and presentation as well as interference with the secretion of immunoregulatory molecules such as IL-1 ${ }^{5}$. In contrast to the other flaviviruses studied, BUSV slightly increased the synthesis of IL- $1 \beta$ by macrophages stimulated with LPS. These data corroborate the idea that, even though coming from same family, viruses can act differently on the host immune system. Augmented IL-1 $\beta$ production was also seen in culture supernatants of spleen cells from dengue type 2 virus-infected mice stimulated with sheep red blood cells. The authors suggest that the IL-1 $\beta$ rise could explain the fever observed in the acute phase of dengue infections ${ }^{23}$.

TGF- $\beta$ has an important role as inhibitor of several effects induced by other cytokines, such as IL- 1 and TNF- $\alpha$. It is considered to be an essential cytokine for the immune response balance ${ }^{12,37}$. In the present study, non-activated macrophages infected with flavivirus did not change the production of TGF- $\beta$. However, when the macrophages were infected with YFV, ROCV and SLEV and stimulated with LPS, a significant inhibition of TGF- $\beta$ synthesis was observed $48 \mathrm{~h}$ post infection. Only BUSV infection was unable to reduce the LPS-stimulated synthesis of TGF- $\beta$ by macrophages.

The infection of murine macrophages with the four Brazilian flaviviruses generated high levels of NO. NO is a potent microbicidal and tumoricidal agent produced by the enzymatic conversion of L-arginine to L-citrulline by nitric oxide synthase (NOS) in the presence of $\mathrm{NADPH}^{20}$. High levels of NO have been shown to play a role in antiviral defense, in particular against several Poxviridae, herpes simplex virus type $1^{9,24}$. NO may serve as one of the mediators controlling viral load during natural dengue virus infection ${ }^{6,30}$. Mortality was significantly increased in JEV-infected mice treated in vivo with L-NMMA, that reduces NO production.

To evaluate the contribution of NO to the outcome of Brazilian flavivirus infection and replication, we infected macrophages with ROCV in the presence of L-NMMA and inoculated mice IC with the cell culture supernatants. Our results showed that even macrophages infected in the presence of L-NMMA, which produced much less NO, did not alter the viral infective rate since IC inoculation of their supernatants induced a mortality rate similar to that observed in the supernatants from only virus-infected macrophages. Taken together, the data obtained suggest that, at least for ROCV, NO is not relevant in restraining virus infectivity. Likewise, tick-borne encephalitis flavivirus (TBEV) also stimulated the production of $\mathrm{NO}$ in murine macrophages in vitro and did not display an inhibitory influence on TBE virus replication. Additionally, the in vivo administration of aminoguanidine, a competitive inhibitor of $\mathrm{NO}$ production, to TBE-virus- infected mice significantly increased their mean survival time, indicating that NO possibly has a pathological effect on the host ${ }^{26}$

As expected, LPS triggered NO synthesis by the cultured macrophages. Moreover, an additive or synergistic production of NO after LPS stimulation could be seen in macrophages infected with ROCV and SLEV. Conversely, YFV virus significantly inhibited LPS-stimulated NO synthesis, while BUSV left NO production unchanged.

Finally, we provide new insights into murine macrophage biology by demonstrating that they are capable of supporting Brazilian flavivirus replication and that each virus tested can selectively regulate cytokines and NO synthesis, thereby disturbing host immune homeostasis.

\section{RESUMO}

\section{Produção de citocinas e óxido nítrico por macrófagos de camundongos infectados com flavivírus brasileiros}

A família Flaviviridae, gênero flavivírus inclui vírus que são transmitidos para os vertebrados por mosquitos e carrapatos. O gênero flavivirus inclui uma variedade de vírus que causa doenças como febres, encefalites e febres hemorrágicas. Primeiramente, as flaviviroses infectam monócitos do sangue e macrófagos do tecido, o qual tem mostrado ser permissivo, suportando a replicação viral e servindo como reservatório de vírus. Por outro lado, essas células podem ter uma importante atividade antiviral relacionada à modulação pela produção de citocinas e pela capacidade destas células sintetizar reativos de radicais livres como óxido nítrico (NO) o qual tem efeito microbicida. O presente estudo foi 
BARROS, V.E.D.; FERREIRA, B.R.; LIVONESI, M. \& FIGUEIREDO, L.T.M. - Cytokine and nitric oxide production by mouse macrophages infected with Brazilian flaviviruses. Rev. Inst. Med. trop. S. Paulo, 51(3): 141-147, 2009.

realizado a fim de determinar a produção de citocinas interleucina - 1 beta (IL-1 $)$, fator de necrose tumoral-alfa (TNF- $\alpha$ ), fator de crescimento transformador-beta (TGF- $\beta$ ), interferon - alfa (IFN- $\alpha$ ) e NO pelos macrófagos infectados com os quatros flavivírus como vírus Bussuquara (BUSV), vírus da febre amarela (YFV), vírus Rocio (ROCV) e vírus da Encefalite de Saint Louis (SLEV), e verificar o possível efeito antiviral de NO durante a infecção dos macrófagos com ROCV. Além disso, com os diferentes vírus foram capazes de regular o lipopolissacarídeo bacteriano (LPS) indutor da produção de citocinas. Nossos resultados mostraram que YFV e SLEV reduziram a produção de IL- $1 \beta$ e TGF- $\beta$ quando macrófagos foram estimulados pelo LPS, enquanto ROCV somente diminuiu a síntese de TGF- $\beta$ estimulada pelo LPS. Entretanto, BUSV favoreceu uma acentuada produção de IL-1 $1 \beta$ pelos macrófagos estimulados pelo LPS, enquanto os vírus estimularam a produção de IFN- $\alpha$, nenhum deles alterou a produção de TNF- $\alpha$ pelos macrófagos murinos. Interessantemente, todos os vírus induziram a síntese de NO que não esteve correlacionada com a atividade antiviral pelo ROCV.

\section{ACKNOWLEDGEMENTS}

We acknowledge Mrs. Soraya Jabur Badra for the cell culture work, Dra. Maria Celia Jamur and Dra. Constance Oliver for help with the indirect immunofluorescence technique, Mrs. Kátia dos Santos, and Mrs. Giuliana Francisco for skilled technical assistance with the microplate reader spectrophotometer (EMAX Molecular Devices Corporation), Mr. Adalberto Verceve and Mr. Mauricio Arantes for helping with virus inoculation in rabbits, and Dr. Fernando Cunha and Dr. João Santana da Silva for helping with cytokine and NO quantification. Research supported by the State of São Paulo Research Council (FAPESP), Brazil.

\section{REFERENCES}

1. AKAIKE, T. \& MAEDA, H. - Nitric oxide and virus infection. Immunity, 101: $300-308,2000$

2. BARROS, V.E.; THOMAZINI, J.A. \& FIGUEIREDO, L.T.M. - Cytopathological changes induced by selected Brazilian flaviviruses in mouse macrophages. $\mathbf{J}$. Microsc., 216: 5-14, 2004.

3. BRINTON, M.A.; FERNANDEZ, A.V. \& AMATO, J. - The 3 `nucleotides of flavivirus genomic RNA form a conserved secondary structure. Virology, 153: 113-121, 1986.

4. CHAMBERLAIN, R.W. - Epidemiology of arthropod-borne togaviruses. The role of arthropods as hosts and vectors and of vertebrate hosts in natural transmission cycles. In: SCHLESINGER, R.W. ed. The togaviruses, biology structure, replication. New York, Academic, 1980. p.145- 228.

5. CHANG, D.M. \& SHAIO, M.F. - Production of interleukin-1 (IL-1) and IL-1 inhibitor by human monocytes exposed to dengue virus. J. infect. Dis., 170: 811-817, 1994.

6. CHARNSILPA, W.; TAKHAMPUNYA, R.; ENDY, T.P. et al. - Nitric oxide radical suppresses replication of wild-type dengue 2 viruses in vitro. J. med. Virol., 77: 89-95, 2005.

7. CHATURVEDI, U.C.; AGARWAL, R.; ELBISHBISHI, E.A. \& MUSTAFA, A.S. Cytokine cascade in dengue hemorrhagic fever: implications for pathogenesis. FEMS Immunol. med. Microbiol., 28: 183-188, 2000.

8. CHEN, Y.C. \& WANG, S.Y. - Activation of terminally differentiated human monocytes/ macrophages by dengue virus: productive infection, hierarchical production of innate cytokines and chemokines, and the synergistic effect of lipopolysaccharide. J. Virol., 76: $9877-9887,2002$.
9. CROEN, K.D. - Evidence for antiviral effect of nitric oxide. Inhibition of herpes simplex virus type 1 replication. J. clin. Invest., 91: 2446-2452, 1993.

10. DA FONSECA, B.A. \& FONSECA, S.N. - Dengue virus infections. Curr. Opin. Pediat., 14: 67-71, 2002

11. DIAMOND, M.S.; ROBERTS, T.G.; EDGIL, D. et al. - Modulation of dengue virus infection in human cells by alpha, beta, and gamma interferons. J. Virol., 74: 49574966, 2000

12. DINARELLO, C.A. - Interleukin-1 (IL-1). In: THOMSON, A.W., ed. The cytokine handbook. 2. ed. New York, Academic Press, 1994. p. 31-56.

13. DING, A.H.; NATHAN, C.F. \& STUEHR, D.J. - Release of reactive nitrogen intermediates and reactive oxygen intermediates from mouse peritoneal macrophages. Comparison of activating cytokines and evidence for independent production. J. Immunol., 141: 2407-2411, 1988.

14. EL MEKKI, A.A. \& VAN DER GROEN, G. - A comparison of indirect immunofluorescence and electron microscopy for the diagnosis of some haemorrhagic viruses in cell cultures. J. virol. Meth., 3: 61-69, 1981.

15. ESPINA, L.M.; VALERO, N.J.; HERNÁNDEZ, J.M. \& MOSQUERA, J.A. Increased apoptosis and expression of tumor necrosis factor caused by infection of cultured human monocytes with dengue virus. Amer. J. trop. Med. Hyg., 68: 48-53, 2003.

16. FIGUEIREDO, L.T. - The Brazilian flaviviruses. Microbes Infect., 2: 1643-1649, 2000 .

17. GOSSELIN, J.; FLAMAND, L.; D’ADDARIO, M. et al. - Modulatory effects of Epstein-Barr, herpes simplex, and human herpes-6 viral infections and coinfections on cytokines synthesis. A comparative study. J. Immunol., 149: 181-187, 1992.

18. GUPTA, M.; MAHANTY, S.; AHMED, R. \& ROLLIN, P.E. - Monocyte-derived human macrophages and peripheral blood mononuclear cells infected with Ebola virus secrete MIP- $1 \alpha$ and TNF- $\alpha$ and inhibit poly-IC-Induced IFN- $\alpha$ in vitro. Virology, 284: $20-25,2001$.

19. HASEGAWA, H.; SATAKE, Y. \& KOBAYASHI, Y. - Effect of cytokines on Japanese encephalitis virus production by human monocytes. Microbiol. Immunol., 34: 459466, 1990.

20. HIBBS, J.B.; TAINTOR, R.; VAVRIN, Z. \& RACHLIN, E.M. - Nitric oxide a cytotoxic activated macrophage effector molecule. Biochem. Biophys. Res. Commun., 157: 87-94, 1988.

21. HOOFNAGLE, J.H. - Therapy of acute and chronic viral hepatitis. Adv. intern. Med., 39: 241-275, 1994.

22. HUNG, S.L.; LEE, P.L.; CHEN, H.W. et al. - Analysis of the steps involved in dengue virus entry into host cells. Virology, 257: 156-167, 1999.

23. ISLAS-RODRIGUEZ, A.E.; RAMOS, J. \& RAMOS, C. - Effect of in vitro infection with dengue virus (DEN-2) on various cellular immune response functions in the mouse. Arch. invest. Med., 2: 87-93, 1990.

24. KARUPIAH, G.; XIE, Q.W.; BULLER, R.M. et al. - Inhibition of viral replication by interferon - $\boldsymbol{\gamma}$ - induced nitric oxide synthase. Science, 261: 1445-1448, 1993.

25. KREIL, T.R. \& EIBL, M.M. - Viral infection of macrophages profoundly alters requirements for induction of nitric oxide synthesis. Virology, 212: 174-178, 1995.

26. KREIL, T.R. \& EIBL, M.M. - Nitric oxide and viral infection: no antiviral activity against a flavivirus in vitro and evidence for contribution to pathogenesis in experimental infection in vivo. Virology, 219: 304-306, 1996. 
27. LIBRATY, D.H.; PICHYANGKUL, S.; AJARIYAKHAJORN, C.; ENDY, T.P. \& ENNIS, F.A. - Human dendritic cells are activated by dengue virus infection enhancement by gamma interferon and implications for disease pathogenesis. J. Virol., 75: 3501-3508, 2001.

28. MANNHALTER, J.W.; BORTH, W. \& EIBL, M.M. - Modulation of antigen-induced cell proliferation by alpha ${ }_{2}$ M-trypsin complexes. J. Immunol., 136: 2792-2799, 1986

29. MOGENSEN, S.C. - Role of macrophages in natural resistance to virus infections. Microbiol. Rev., 43: 1-26, 1979.

30. NEVES-SOUZA, P.C.F.; AZEREDO, E.L.; ZAGNE, S.M.O. et al. - Inducible nitric oxide synthase (iNOS) expression in monocytes during acute dengue fever in patients and during in vitro infection. BMC infect. Dis., 5: 64, 2005.

31. PINTO, A.J.; MORAHAN, P.S.; BRINTON, M.; STEWART, D. \& GAVEN, E. - Comparative therapeutic efficacy of recombinant interferons- alpha-beta, and gamma against alphatogaviruses, bunyavirus, flavivirus, and herpesvirus infections. J. Interferon Res., 10: 293-298, 1990.

32. PLATANIAS, L.C.; UDDIN, S.; DOMANSKI, P. \& COLAMONICI, O.R. Differences in interferon alpha and beta signaling. Interferon beta selectively induces the interaction of the alpha and beta L subunits of the type I interferon receptor. J. biol. Chem., 271: 23630-23633, 1996.
33. REED, L.J. \& MUENCH, H. - A simple method of estimating fifty percent age end points. Amer. J. Hyg., 27: 493-497, 1938.

34. SAXENA, S.K.; SINGH, A. \& MATHUR, A. - Antiviral effect on nitric oxide during Japanese encephalitis virus infection. Int. J. exp Path., 81: 165-172, 2000.

35. STARK, G.R.; KERR, I.M.; WILLIAMS, B.R.; SILVERMAN, R.H. \& SCHREIBER R.D. - How cells respond to interferons. Ann. Rev. Biochem., 67: 227-264, 1998.

36. VITHANOMSAT, S.; WASI, C.; HARINASUTA, C. \& THONGCHAROEN, P. - The effect of interferon on flaviviruses in vitro: a preliminary study. Southeast Asian J. trop. Med. publ. Hlth, 15: 27-31, 1984.

37. WAHL, S.M.; MC CARTNEY-FRANCIS, N. \& MERGENHAGEN, S.E. Inflammatory and immunomodulatory roles TGF-beta. Immunol. today, 10: 258-261, 1989

38. WENGLER, G.- Family Flaviviridae. In: FRANCKI, T.B.; FAUGUET, C.M.; KNUDSON, D.L. \& BROWN, F., ed. Classification and nomenclature of viruses. Fifth report of the International Committee on Taxonomy of Viruses. Arch. Virol., 2(suppl. 2): 230-231, 1991.

Received: 7 August 2008

Accepted: 27 April 2009 